\title{
Caspase-4 and caspase-5, members of the ICE/CED-3 family of cysteine proteases, are CrmA-inhibitable proteases
}

\author{
Shinji Kamada ${ }^{1}$, Yoshimitsu Funahashi ${ }^{1}$ and \\ Yoshihide Tsujimoto, \\ ${ }^{1}$ Department of Medical Genetics, Biomedical Research Center, Osaka \\ University Medical School, 2-2 Yamadaoka, Suita, Osaka 565, Japan \\ 2 Corresponding author: Department of Medical Genetics, Biomedical Research \\ Center, Osaka University Medical School, 2-2 Yamadaoka, Suita, Osaka 565, \\ Japan tel: +81-6-879-3360; fax: +81-6-879-3369 \\ e-mail: tsujimot@gene.med.osaka-u.ac.jp
}

Received 12.2.97; revised 19.3.97; accepted 10.4.97

Edited by Y. Kuchino

\begin{abstract}
Proteases of the caspase family are implicated in mammalian apoptosis and constitute a protease cascade. We character-

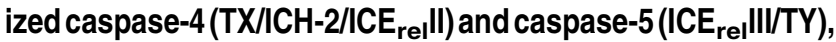
which are most closely related to caspase-1 (ICE) among the caspase family. Although overexpression of caspase- 4 and caspase- 5 induced apoptosis, confirming previous observations, this apoptosis was not inhibited by a caspase-1-specific tetrapeptide inhibitor (AC-YVAD-CHO), suggesting that caspase- 4 and caspase- 5 have different substrate specificities from caspase-1 and also that caspase-4- and caspase-5induced apoptosis is not mediated by caspase-1. CrmA, a cowpox virus-derived caspase- 1 inhibitor that prevents apoptosis induced by various stimuli, was cleaved by caspase- 4 and caspase- 5 , and inhibited their proteolytic activity as assessed by cleavage of pro-caspase-3 (proCPP32/Yama/apopain). Thus, caspase -4 and caspase -5 are CrmA-inhibitable proteases like caspase-1 and might be involved in apoptosis.
\end{abstract}

Keywords: Apoptosis; cysteine protease; caspase-4; caspase-5; CrmA; baculovirus p35

Abbreviations: ICE, interleukin- $1 \beta$-converting enzyme; TNF, tumour necrosis factor; PAGE, polyacrylamide gel electrophoresis

\section{Introduction}

Apoptosis, or programmed cell death, is a fundamental process crucial to morphogenesis and the maintenance of homeostasis in both vertebrates and invertebrates. Genetic studies in the nematode Caenorhabditis elegans have led to the isolation of genes, including ced-3, ced-4 and ced-9, that are involved in programmed cell death (Yuan and Horvitz,
1990; Hengartner et al, 1992). ced-3 and ced-4 are required for such cell death to occur. ced-3 encodes a protein that is similar to interleukin-1 $\beta$ (IL-1 $\beta$ )-converting enzyme (ICE), a cysteine protease that cleaves the inactive $31 \mathrm{kDa}$ precursor of IL-1 $\beta$ to generate the active cytokine (Thornberry et al, 1992; Yuan et al, 1993). Ten proteins homologous to ICE (caspase-1) have been identified in mammals and are classified into three subfamilies, caspase-1-, caspase-3 (CPP32/Yama/apopain)-, and caspase-2 (NEDD2/ICH-1)like proteases, based on their structures (Alnemri et al, 1996). The caspase-1-like subfamily includes caspase-1 (Thornberry et al, 1992), caspase-4 (TX/ICH-2/ICE $\mathrm{rel}_{\mathrm{II}}$ ) (Faucheu et al, 1995; Kamens et al, 1995; Munday et al,

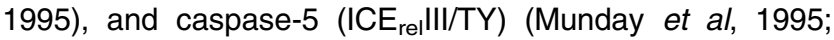
Faucheu et al, 1996). The caspases have been suggested to constitute a protease cascade (Martin and Green, 1995; Enari et al, 1996; Shimizu et al, 1996). Among the caspase family, caspase-1(-like) and caspase-3(-like) proteases have been implicated in physiological cell death, based upon the inhibition of cell death by tetrapeptide inhibitors of caspase-1 and caspase-3 (Los et al, 1995; Milligan et al, 1995; Nicholson et al, 1995; Enari et al, 1996; Chen et al, 1996; Jacobson et al, 1996; Schlegel et al, 1996; Hasegawa et al, 1996; Dubrez et al, 1996). Studies of a shorter isoform of caspase-2 have also revealed its involvement in cell death (Wang et al, 1994). However, roles of other members of this family in cell death remain to be elucidated. Since apoptosis induced by a variety of stimuli is inhibited by baculovirus p35 (Clem et al, 1991; Rabizadeh et al, 1993; Hay et al, 1994; Sugimoto et al, 1994; Beidler et al, 1995), which inhibits the activities of caspases (Xue and Horvitz, 1995; Bump et al, 1995), and by a cowpox virus-derived caspase-1 inhibitor, CrmA (Pickup et al, 1986; Ray et al, 1992; Gagliardini et al, 1994; Tewari and Dixit, 1995; Los et al, 1995; Enari et al, 1995; Tewari et al, 1995b; Smith et al, 1996; Li et al, 1996), it would be interesting to identify CrmA-inhibitable members of the caspase family.

In the present study, we characterized caspase- 4 and caspase-5, which are most closely related to caspase-1 among the caspase family, and showed that these two proteases have similar substrate preferences and are both CrmA-inhibitable.

\section{Results \\ Caspase-4- and caspase-5-induced apoptosis is not inhibited by Ac-YVAD-CHO}

Among the caspase family, caspase- 4 and caspase- 5 are most closely related to caspase-1 (53\% identity for caspase-4 and $51 \%$ identity for caspase-5). To study the apoptosisinducing activity of caspase- 4 and caspase-5, we employed the same transient expression system as that previously used for caspase-1 (Miura et al, 1993). We fused human caspase-4 
and caspase- 5 cDNAs in frame with the $E$. coli lacZ gene and placed the fused gene under the control of the chicken $\beta$-actin promoter in pcas-4-lacZ and pcas-5-lacZ, respectively. We also used constructs of the fusion gene of the caspase- 1 and caspase- $2_{L}$ cDNAs with the lacZ gene, pcas-1-lacZ and $\mathrm{p} \beta$ actH37Z (Wang et al, 1994), respectively. The fusion genes were transfected into Rat-1 cells and their expression was examined with the X-Gal reaction. Most blue Rat- 1 cells (XGal-positive) transfected with the lac $Z$ gene alone were flat and well attached to the plates (data not shown). In contrast, most blue cells transfected with pcas-4-lacZ and pcas-5-lacZ contained round or small membrane-bound fragments representing apoptotic bodies, similar to those in cells transfected with pcas-1-lacZ and $\mathrm{p} \beta$ actH37Z. These results indicate that overexpression of caspase- 4 and caspase- 5 proteins induces Rat-1 cells to undergo apoptosis, confirming previous observations (Faucheu et al, 1995; Kamens et al, 1995; Munday et al, 1995). The tetrapeptide caspase-1 inhibitor Ac-YVAD-CHO (Thornberry et al, 1992) effectively blocked caspase-1-induced apoptosis in a concentrationdependent manner, whereas caspase-4-, caspase-5- and caspase-2 $\mathrm{L}_{\mathrm{L}}$-induced apoptosis was not significantly inhibited (Figure 1). These findings suggest that caspase- 4 and caspase- 5 have different substrate specificities from caspase- 1 and also that caspase-4-, caspase-5-, and caspase$2 \mathrm{~L}$-induced apoptosis are not mediated by caspase- 1 .

\section{Caspase- 4 and caspase- 5 show similar substrate preferences in the in vitro cleavage assay}

We compared the substrate preferences of caspase- 4 and caspase- 5 with cowpox virus $\mathrm{CrmA}$, baculovirus $\mathrm{p} 35$, and pro-

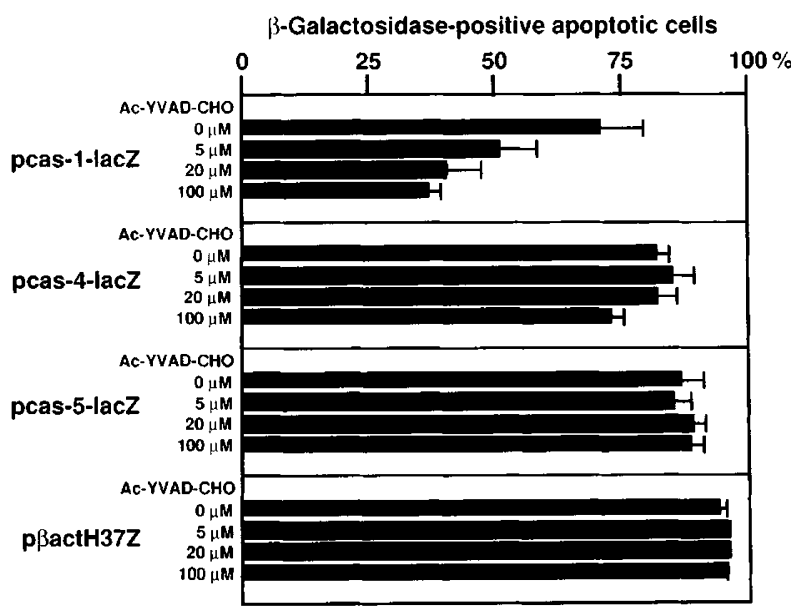

Figure 1 Effect of Ac-YVAD-CHO on caspase-1-, caspase-4-, caspase-5-, and caspase-2L-induced apoptosis. One day after plating Rat-1 cells at a density of $2 \times 10^{5}$ in each well of 6 -well dishes, $1.0 \mu \mathrm{g}$ of the indicated DNA constructs was transfected. $\mathrm{p} \beta$ actH $37 \mathrm{Z}$ is the caspase- $2_{\mathrm{L}}$-expressing construct (Wang et al, 1994). The cells were incubated for $3 \mathrm{hr}$ in serumfree medium containing DNA and lipofectamine, washed with serum-free medium, cultured in medium containing 10\% FBS and the indicated concentrations of inhibitor (Ac-YVAD-CHO) for an additional $20 \mathrm{~h}$ and stained with X-Gal. The percentages (mean \pm S.D.) of morphologically apoptotic cells among all $\beta$-galactosidase-positive blue cells are shown. More than 500 blue cells were counted in three independent experiments. caspase-3 as potential substrates using recombinant proteases and in vitro translated ${ }^{35} \mathrm{~S}$-labeled substrates. The results are summarized in Table 1. Caspase- 4 and caspase- 5

a

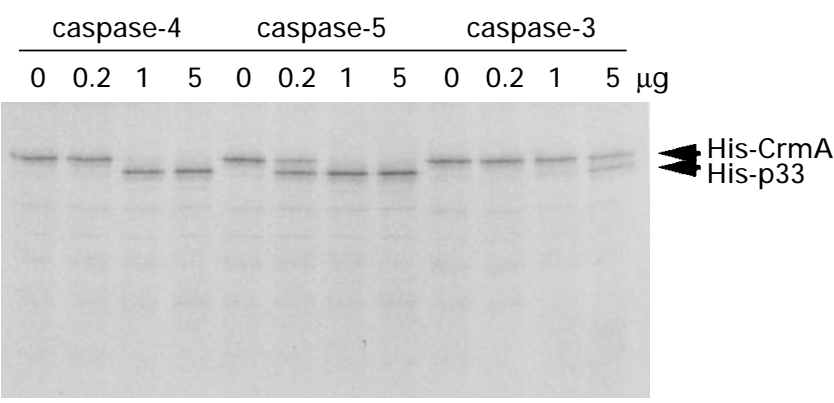

caspase-4 caspase- 5 caspase- 3

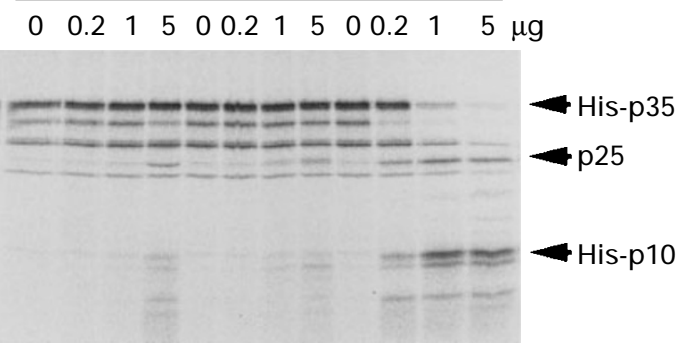

caspase-4 caspase-5 caspase-3

$\begin{array}{llllllllllllll}0 & 0.2 & 1 & 5 & 0 & 0.2 & 1 & 5 & 0 & 0.2 & 1 & 5 \mu \mathrm{g}\end{array}$

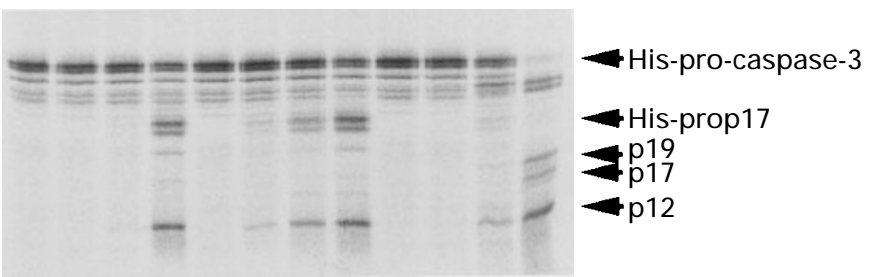

Figure 2 Substrate preferences of recombinant caspase-4 and caspase-5. (A) Cleavage of CrmA by recombinant caspase-4, caspase-5, and caspase- 3 . ${ }^{35} \mathrm{~S}$-labeled $\mathrm{CrmA}$ protein was incubated with the indicated amounts of purified caspase- 4 , caspase- 5 , or caspase- 3 for $3.5 \mathrm{~h}$ and reaction products were analyzed by $15 \%$ SDS-PAGE. The His-p33 band corresponds to the Histagged amino-terminal cleavage product resulting from cleavage at Asp-304. The $5 \mathrm{kDa}$ carboxy-terminal cleavage product was not seen because it contains no methionine residues. (B) Cleavage of baculovirus p35 by caspase-4, caspase-5, and caspase- $3 .{ }^{35}$ S-labeled p35 protein was incubated with purified caspase- 4 , caspase- 5 , or caspase- 3 and the reaction products were analyzed as described in $(\mathbf{A})$. The p25 band corresponds to the carboxy-terminal cleavage product resulting from cleavage at Asp-87. The His-p10 bands correspond to the His-tagged amino-terminal cleavage product. (C) Cleavage of pro-caspase- 3 by caspase- 4 , caspase-5, and caspase- $3 .{ }^{35} \mathrm{~S}$ labeled mutant pro-caspase- 3 protein was incubated with purified caspase-4, caspase-5, or caspase- 3 and the reaction products were analyzed as described in (A). The $\mathrm{p} 17$ and $\mathrm{p} 12$ bands correspond to two subunits of active caspase-3. The His-prop17 bands may be the His-tagged prodomain with the 17 subunit resulting from cleavage at Asp-175. The 19 band may be the amino-terminal cleavage product resulting from cleavage at Asp-9 and Asp-175. 
proteases showed a preference for CrmA rather than p35 as a substrate, whereas caspase- 3 effectively cleaved p35 and only poorly cleaved CrmA (Figure $2 \mathrm{a}$ and b). As shown in Figure 2c, purified recombinant caspase-3 cleaved procaspase- 3 bearing active site mutations at both $\mathrm{p} 17$ and p12 (subunits of the active enzyme) to generate p12 and p17, confirming previous observations (Wang et al, 1996; Xue et al, 1996). Purified recombinant caspase- 4 and caspase- 5 also cleaved pro-caspase-3 to generate p12 and pro-p17 (Figure $2 c)$. The in vitro cleavage of $\mathrm{CrmA}$, baculovirus $\mathrm{p} 35$, and mutant pro-caspase- 3 by caspase- 4 , caspase- 5 , and caspase-3 was dependent on the concentration of the respective protease. Lysates of bacteria expressing the respective proteases cleaved the substrates, but not lysates of bacteria with a control vector (data not shown), indicating that cleavage was not due to contaminating bacterial proteases. These data show that caspase- 4 and caspase- 5 have a similar substrate preference for CrmA and p35.

\section{CrmA inhibits cleavage of pro-caspase- 3 by caspase-4 and caspase- 5}

Detection of the cleavage of CrmA by caspase- 4 and caspase- 5 led us to examine whether CrmA directly inhibits the proteolytic activities of caspase- 4 and caspase -5 using the in vitro cleavage assay. As shown in Figure $3, \mathrm{CrmA}$ effectively inhibited the cleavage of pro-caspase- 3 by recombinant caspase- 4 and caspase-5, indicating that caspase- 4 and caspase- 5 are CrmA-inhibitable proteases.

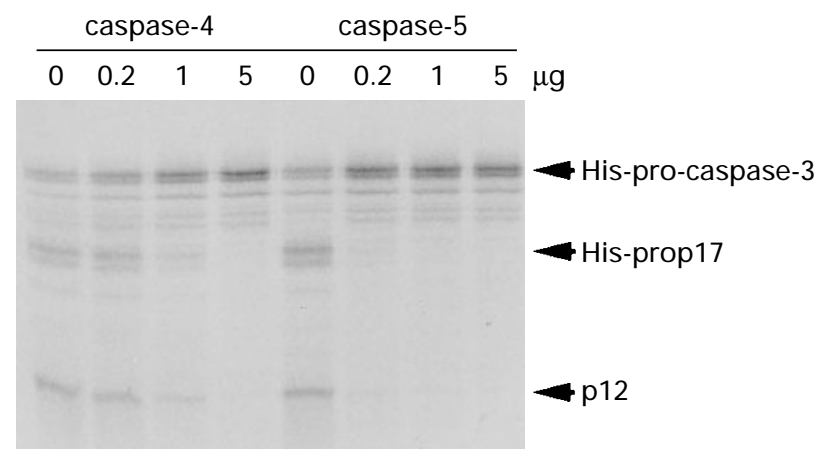

Figure 3 CrmA-mediated inhibition of the cleavage of pro-caspase- 3 by caspase- 4 and caspase-5. ${ }^{35} \mathrm{~S}$-labeled mutant pro-caspase- 3 protein was incubated with $5 \mu \mathrm{g}$ of purified caspase- 4 and caspase- 5 and the indicated amounts of purified $\mathrm{CrmA}$ for $3.5 \mathrm{~h}$ after which the reaction products were analyzed by $15 \%$ SDS-PAGE.

Table 1 Substrate preferences of caspase-3, caspase-4, and caspase-5

\begin{tabular}{lc}
\hline Protease & Substrate \\
\hline caspase-4 & CrmA $>$ pro-caspase-3>p35 \\
caspase-5 & CrmA $>$ pro-caspase-3>p35 \\
caspase-3 & p35>pro-caspase-3>CrmA \\
\hline
\end{tabular}

Substrate preference was assessed by the extent of cleavage of three substrates with the respective protease at fixed concentrations. Data from Figure 2 are summarized here.

\section{Caspase-4- and caspase-5-induced apoptosis is inhibited by CrmA}

To further confirm the inhibitory effect of CrmA on caspase-4 and caspase- 5 in vivo, Rat- 1 cells were cotransfected with lacZ fusion plasmids (pcas-1-lacZ, pcas-4-lacZ, pcas-5-lacZ, and $\mathrm{p} \beta$ actH37Z) together with a $\mathrm{crmA}$ expression construct (pCAG-crmA). As shown in Figure 4, apoptosis induced by overexpression of caspase- 4 and caspase- 5 was inhibited by CrmA as effectively as caspase-1-induced apoptosis. In contrast, caspase-2L-induced apoptosis was not affected by CrmA, confirming the previous observation (Wang et al, 1994).

\section{Discussion}

The implication of caspase-1 in physiological cell death is based upon the prevention of apoptosis by inhibitors of the protease, including a tetrapeptide caspase-1 inhibitor AcYVAD-CHO (Los et al, 1995; Milligan et al, 1995; Enari et al, 1996; Chen et al, 1996), that was prepared based on the cleavage site in prolL-1 $\beta$ (Thornberry et al, 1992). However, it has not previously been determined whether Ac-YVAD-CHO only inhibits caspase-1. We showed that apoptosis induced by caspase- 4 and caspase- 5 , which are most closely related to caspase-1, was not inhibited by Ac-YVAD-CHO, a finding consistent with the previous observation that caspase- 4 and caspase-5 could not cleave prolL-1 $\beta$ (Faucheu et al, 1995, 1996; Munday et al, 1995). Although the Ki of caspase-1 inhibition by Ac-YVAD-CHO is $<1 \mathrm{nM}$, caspase-1-induced apoptosis is only partially inhibited by $100 \mu \mathrm{M}$ inhibitor. This is probably due to poor cell permeability of the tetrapeptide inhibitor. Thus, the available data suggest that Ac-YVAD$\mathrm{CHO}$ is a quite specific inhibitor of caspase-1 itself.

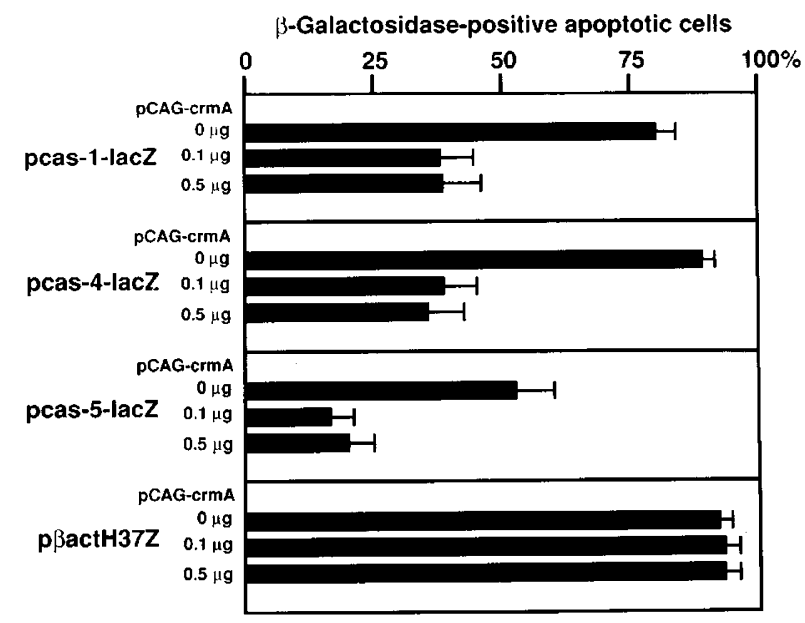

Figure 4 Effects of CrmA on caspase-1-, caspase-4-, caspase-5- and caspase-2 $2_{L}$-induced apoptosis. One day after plating Rat-1 cells at a density of $2 \times 10^{5}$ in each well of 6 -well dishes, $0.1 \mu \mathrm{g}$ of the indicated plasmids and various amount of pCAG-crmA or pUC-CAGGS were transfected in a total of $1.0 \mu \mathrm{g}$ of DNA. The cells were incubated for $3 \mathrm{~h}$ in serum-free medium containing DNA and lipofectamine. Then a threefold volume of medium containing $10 \%$ FBS was added without removing the transfection mixture, and incubation was done for $22 \mathrm{~h}$ followed by staining with X-Gal. The data (mean \pm S.D.) were analyzed as described in the legend to Figure 1 . 
Xue et al. (1996) suggested that caspases could be categorized by their ability to cleave CrmA and p35 after studying CED-3, caspase-3, caspase-1, and caspase-2; CED-3 and caspase- 3 effectively cleave pro-caspase- 3 and baculovirus p35 but not CrmA, caspase- 1 effectively cleaves CrmA, and caspase-2 weakly cleaves only baculovirus p35. The preference of caspase-4 and caspase-5 for CrmA rather than baculovirus p35 as a substrate (Figure 2 and Table 1) suggests that these proteases are functionally related to caspase-1, consistent with the findings on structural analysis.

The cowpox virus gene product CrmA is a potent inhibitor of caspase-1 (Ray et al, 1992) and has also been shown to inhibit the induction of apoptosis by various stimuli. CrmA efficiently inhibits granzyme $B$, but only inhibits caspase-3 and caspase-7 (Mch3/ICE-LAP3/CMH1) at high concentrations (Quan et al, 1995; FernandesAlnemri et al, 1995). Here, we have shown that CrmA efficiently inhibits caspase- 4 and caspase- 5 . It was recently reported that a Fas-associated caspase family protease, caspase-8 (MACH/FLICE/Mch5) (Boldin et al, 1996; Muzio et al, 1996; Fernandes-Alnemri et al, 1996), is a CrmAinhibitable protease (Srinivasula et al, 1996). This suggests that caspase- 8 is the critical target of CrmA when inhibiting Fas- and TNF-induced apoptosis, because caspase-8 appears to be a protease that is furthest upstream in the caspase cascade. It is not known whether caspase- 8 is generally involved in apoptosis. However, since caspase-4 and caspase- 5 are also CrmA-inhibitable protease, they may be involved in CrmA-inhibitable physiological apoptosis triggered by a variety of stimuli.

The caspase cascade is implicated in the apoptotic cell death pathway (Enari et al, 1996; Shimizu et al, 1996). In Fas-mediated apoptosis, caspase-1(-like) proteases seem to act downstream of caspase-8 and/or Mch-4 (caspase-10) (Srinivasula et al, 1996) and upstream of caspase-3(-like) protease (Enari et al, 1996). We have recently shown that a caspase-4(-like) protease is involved in Fas-mediated apoptosis, probably by transducing a death signal directly to caspase-3(-like) proteases (Kamada et al, 1997). Since caspase- 4 and caspase- 5 cleave pro-caspase- 3 to release p12 but not p17, both of which are components of active caspase-3, the generation of p17 might be mediated by other members of caspase family. Alternatively, the release of p12 might lead to auto-activation of caspase-3. In vitro cleavage of pro-caspase- 3 by caspase- 5 suggests that caspase- 5 as well as caspase- 1 and caspase- 4 might be involved in physiological apoptotic cell death by activating caspase-3(-like) proteases. Thus, multiple protease cascade pathways might exist to activate caspase-3(-like) proteases, one of the executioner protease

\section{Materials and Methods}

\section{Cell culture}

Rat-1 cells were grown in Dulbecco's modified Eagle's medium (DMEM) supplemented with $10 \%$ fetal bovine serum (FBS). Transfection was performed using Lipofectamine (Life Technologies) according to the manufacturer's instructions. For analysis of $\beta$ - galactosidase expression, cells were rinsed once with phosphatebuffered saline (PBS), fixed with $1 \%$ glutaraldehyde for $5 \mathrm{~min}$, rinsed twice with PBS, and stained in X-Gal buffer $(0.5 \mathrm{mg} / \mathrm{ml} 5$-bromo-4chloro-3-indoxyl $\beta$-galactoside, $3 \mathrm{mM} \mathrm{K}_{3} \mathrm{Fe}(\mathrm{CN})_{6}, 3 \mathrm{mM} \mathrm{K} \mathrm{K}_{4} \mathrm{Fe}(\mathrm{CN})_{6}$ $3 \mathrm{H} 20,1 \mathrm{mM} \mathrm{MgCl}_{2}, 10 \mathrm{mM} \mathrm{KCl}, 0.1 \%$ Triton $\mathrm{X}-100$ in $0.1 \mathrm{M}$ sodium phosphate buffer [pH 7.5]) (Miura et al, 1993) at $37^{\circ} \mathrm{C}$ for $3 \mathrm{~h}$.

\section{Construction of plasmids}

To construct expression plasmids, PCR was carried out using the cDNAs of caspase- 1 , caspase- 4 , and caspase- 5 as templates. The following PCR primers were used: for human caspase-1, C1-5 (5'CGGTCGACAGCCATGGCCGACAAGGTCCTG-3') and C1-3 (5'CGGGTACCCAATGTCCTGGGAAGAGGTAGAA-3'); and for human caspase-4, C4-5 (5'-CGGTCGACCCCTATGGCAGAAGGCAACCAC$\left.3^{\prime}\right)$ and C4-3 (5'-CGGGTACCCAATTGCCAGGAAAGAGGTAGAA-3'); and for human caspase-5, C5-5 (5'-CGGGTACCAGCTATGTTCAAAGGTA-3') and C5-3 (5'-CGGGTACCCAATTGCCAGGAAAGAG-3'). The C1-5 and C4-5 primers had a Sall at the $5^{\prime}$ end, while the C1-3, C4-3, C5-5, and C5-3 primers had a Kpnl site at their $5^{\prime}$ end. The amplified human caspase- 1 and caspase- 4 fragments and the caspase- 5 fragment were respectively cloned into Sall-Kpnl sites and the Kpnl site of $\operatorname{pact} \beta G$ al, which possesses the chicken $\beta$-actin promoter (Maekawa et al, 1991) to generate pcas-1-lacZ, pcas-4-lacZ and pcas-5-lacZ, respectively. In these constructs, the sequences coding for the proteases were joined in-frame to the amino terminal of $\beta$-galactosidase. The same fragments were also cloned into Sall-Kpnl sites and the Kpnl site of pBluescript SK(-) (Stratagene) and sequenced.

The $\mathrm{crmA}$ gene was isolated as a $1.4 \mathrm{~kb}$ EcoRl fragment by digestion of plasmid p996 (Pickup et al, 1986) and was inserted into the EcoRI site of the pUC-CAGGS vector (Niwa et al, 1991), generating $\mathrm{PCAG}-\mathrm{crmA}$.

\section{Purification of recombinant $\mathrm{His}_{6}$-tagged proteases}

DNA sequences encoding the 105-377th amino acid residue of caspase-4, 122-418th amino acid residue of caspase-5 and 29277th amino acid residue of caspase-3 were amplified by PCR and subcloned into the $E$. coli expression vector pRSET A (Invitrogen), in which the protease sequences were placed under the control of the T7 promoter and joined in-frame to sequences encoding an $\mathrm{N}$-terminal fusion peptide, which includes an ATG translation initiation codon and the sequence for six successive histidine residues that function as a metal-binding domain in the translated proteins. The resultant plasmids (pHiscas4, pHiscas5 and pHiscas 3 ) were transformed into E. coli strain JM109. Induction of recombinant $\mathrm{His}_{6}$-tagged proteases was achieved according to the manufacturer's instructions. Cells were harvested and recombinant proteases were purified essentially as described elsewhere (Lippke et al, 1996). Fractions showing proteolytic activity in an in vitro cleavage assay (described below) were pooled and dialyzed against buffer A (50 mM HEPES, $0.1 \mathrm{M}$ $\mathrm{NaCl}, 10 \%(\mathrm{v} / \mathrm{v})$ glycerol, $\mathrm{pH} 7.5)$ to remove excess imidazole and were stored at $-80^{\circ} \mathrm{C}$. The purity of the proteins thus obtained was greater than $80 \%$ for His-caspase- 4 or His-caspase-5, and approximately $20 \%$ for His-caspase-3, as estimated by Coomassie blue staining.

\section{Purification of $\mathrm{His}_{6}$-tagged CrmA protein}

crmA DNA containing the entire coding region was amplified by PCR using the p996 plasmid (Pickup et al, 1986) as a template and two primers, HisCrm5 (5'-CGCTCGAGGAATGGATATCTTCAGG) and 
HisCrm3 (5'-CGGAATTCTTAATTAGTTGTTGG), encompassing the initiation and termination codons of $\mathrm{CrmA}$, respectively. HisCrm5 had an Xhol site at the $5^{\prime}$ end and HisCrm3 had an EcoRl site. The amplified fragment was subcloned into the Xhol-EcoRI sites of pRSET $\mathrm{C}$ to generate pHiscrmA. Expression of $\mathrm{His}_{6}$-tagged $\mathrm{CrmA}$ was achieved according to the manufacturer's instructions. Cells were lyzed by sonication in a buffer containing $20 \mathrm{mM}$ sodium phosphate $(\mathrm{pH} 7.8)$ and $0.5 \mathrm{M} \mathrm{NaCl}$, after which the lysates were cleared by centrifugation. Then the supernatants containing soluble His-CrmA were loaded onto a $1 \mathrm{ml}$ nickel-NTA column (Qiagen) and washed extensively with $20 \mathrm{mM}$ sodium phosphate $(\mathrm{pH} 6.0)$ and $0.5 \mathrm{M} \mathrm{NaCl}$. His-CrmA protein was eluted with $100-200 \mathrm{mM}$ imidazole in $20 \mathrm{mM}$ sodium phosphate $(\mathrm{pH} 7.8)$ and $0.5 \mathrm{M} \mathrm{NaCl}$, and was found to elute at approximately $200 \mathrm{mM}$ imidazole. It was dialyzed against buffer $\mathrm{A}$ to remove excess imidazole and stored at $-80^{\circ} \mathrm{C}$. The protein thus obtained showed greater than $90 \%$ purity by Coomassie blue staining.

\section{In vitro cleavage assay}

To construct an expression plasmid for $\mathrm{His}_{6}$-tagged baculovirus p35, the $1 \mathrm{~kb} \mathrm{Ndel} \mathrm{p35}$ fragment containing entire coding region was blunt-ended and inserted into the Pvull site of PRSET A, generating pHisp35. To substitute Cys 163 for Ser and Arg 207 for Glu in caspase-3, a PCR-based method was used. The final PCR product was cloned into the EcoRI site of pBluescript SK $(-)$ and sequenced. The same fragment encoding caspase-3 containing active site mutations at both $\mathrm{p} 17$ and $\mathrm{p} 12$ subunits was subcloned into $\mathrm{pRSET} A$ to generate pHiscas $3^{\mathrm{m}} .{ }^{35} \mathrm{~S}$-methionine-labeled $\mathrm{His}_{6}$ tagged CrmA, p35 and mutant pro-caspase-3 were prepared for in vitro cleavage assays using expression constructs (pHiscrmA, pHisp35, and pHiscas $3^{\mathrm{m}}$ ) and a TNT T7 coupled in vitro transcription and translation system (Promega) according to the manufacturer's instructions. ${ }^{35} \mathrm{~S}$-methionine-labeled proteins were purified essentially as described elsewhere (Tewari et al, 1995a) and stored at $-80^{\circ} \mathrm{C}$ until use. Recombinant caspase-4, caspase-5, and caspase-3 with or without His-CrmA were preincubated in $20 \mu \mathrm{l}$ of buffer A supplemented with $20 \mu \mathrm{M}$ dithiothreitol at room temperature for $15 \mathrm{~min}$. Reactions were initiated by addition of $20 \mu \mathrm{l}$ of ${ }^{35} \mathrm{~S}$-methionine-labeled proteins and incubation was done at $37^{\circ} \mathrm{C}$ for $3.5 \mathrm{~h}$. The reactions were stopped by the addition of SDSPAGE sample buffer and cleaved products were analyzed by $15 \%$ SDS-PAGE.

\section{Acknowledgements}

This work was supported in part by grants for COE Research, for Scientific Research on Priority Areas and for Scientific Research from the Ministry of Education, Science and Culture of Japan. We wish to thank Dr Jun-ichi Miyazaki for providing the pUC-CAGGS vector plasmid, $\mathrm{Dr}$ Junying Yuan for the pact $\beta$ Gal vector plasmid and $\mathrm{p} \beta$ actH37Z plasmid, Dr Vishva M Dixit for the pcDNA3/Yama plasmid, and Dr David J Pickup for the p996 plasmid containing the $\mathrm{crmA}$ gene.

\section{References}

Alnemri ES, Livingston DJ, Nicholson DW, Salvesen G, Thornberry NA, Wong WW and Yuan J (1996) Human ICE/CED-3 protease nomenclature. Cell 87: 171

Beidler DR, Tewari M, Friesen PD, Poirier G and Dixit VM (1995) The baculovirus p35 protein inhibits Fas- and tumor necrosis factor-induced apoptosis. J. Biol. Chem. 270: $16527-16528$
Boldin MP, Goncharov TM, Goltsev YV and Wallach D (1996) Involvement of MACH, a novel MORT1/FADD-interacting protease, in Fas/APO-1- and TNF receptorinduced cell death. Cell 85: 803-815

Bump NJ, Hackett M, Hugunin M, Seshagiri S, Brady K, Chen P,Ferenz C, Franklin S, Ghayur T, Li P, Licari P, Mankovich J, Shi L, Greenberg AH, Miller LK and Wong WW (1995) Inhibition of ICE family proteases by baculovirus antiapoptotic protein P35. Science 269: 1885-1888

Chen Y, Smith MR, Thirumalai K and Zychlinsky A (1996) A bacterial invasin induces macrophage apoptosis by binding directly to ICE. EMBO J. 15: 3853-3860

Clem RJ, Fechheimer M and Miller LK (1991) Prevention of apoptosis by a baculovirus gene during infection of insect cells. Science 254: 1388-1390

Dubrez L, Savoy I, Hamman A and Solary E (1996) Pivotal role of a DEVD-sensitive step in etoposide-induced and Fas-mediated apoptotic pathways. EMBO J. 15: $5504-5512$

Enari M, Hug H and Nagata S (1995) Involvement of an ICE-like protease in Fasmediated apoptosis. Nature 375: 78-81

Enari M, Talanian RV, Wong WW and Nagata S (1996) Sequential activation of ICElike and CPP32-like proteases during Fas-mediated apoptosis. Nature 380: $723-726$

Faucheu C, Blanchet A-M, Collard-Dutilleul V, Gu Y, Lalanne J-L and Diu-Hercend A (1996) Identification of a cysteine protease closely related to interleukin-1 $\beta$ converting enzyme. Eur. J. Biochem. 236: 207-213

Faucheu C, Diu A, Chen AWE, Blanchet A-M, Miossec C, Herve F, Collard-Dutilleul V, Gu Y, Aldape RA, Lippke JA, Rocher C, Su MS-S, Livingston DJ, Hercend T and Lalanne J-L (1995) A novel human protease similar to the interleukin-1 $\beta$ converting enzyme induces apoptosis in transfected cells. EMBO J. 14: 1914 1922

Fernandes-Alnemri T, Armstrong RC, Krebs J, Srinivasula SM, Wang L, Bullrich F, Fritz LC, Trapani JA, Tomaselli KJ, Litwack G and Alnemri ES (1996) In vitro activation of CPP32 and Mch3 by Mch4, a novel human apoptotic cysteine protease containing two FADD-like domains. Proc. Natl. Acad. Sci. USA. 93: $7464-7469$

Fernandes-Alnemri T, Takahashi A, Armstrong R, Krebs J, Fritz L, Tomaselli KJ, Wang L, Yu Z, Croce CM, Salveson G, Earnshaw WC, Litwack G and Alnemri ES (1995) Mch3, a novel human apoptotic cysteine protease highly related to CPP32. Cancer Res. 55: 6045-6052

Gagliardini V, Fernandez P-A, Lee RKK, Drexler HCA, Rotello R, Fishman M and Yuan J (1994) Prevention of vertebrate neuronal death by the crmA gene. Science 263: 826-828

Hasegawa J, Kamada S, Kamiike W, Shimizu S, Imazu T, Matsuda Hand Tsujimoto Y (1996) Involvement of CPP32/Yama(-like) proteases in Fas-mediated apoptosis. Cancer Res. 56: 1713-1718

Hay BA, Wolff T and Rubin GM (1994) Expression of baculovirus p35 prevents cell death in Drosophila. Development 120: 2121-2129

Hengartner MO, Ellis RE and Horvitz HR (1992) Caenorhabditis elegans gene ced-9 protects cells from programmed cell death. Nature 356: 494-499

Jacobson M, Weil M and Raff MC (1996) Role of Ced-3/ICE-family proteases in staurosporine-induced programmed cell death. J. Cell Biol. 133: 1041-1051

Kamada S, Washida M, Hasegawa J-I, Kusano H, Funahashi $Y$ and Tsujjimoto $Y$ (1997) Involvement of caspase-4-(-like) protease in Fas-mediated apoptotic pathway. Oncogene, in press

Kamens J, Paskind M, Hugunin M, Talanian RV, Allen H, Banach D, Bunp N, Hackett M, Johnston CG, Li P, Mankovich JA, Terranova M and Ghayur T (1995) Identification and characterization of $\mathrm{ICH}-2$, a novel member of the interleukin$1 \beta$-converting enzyme family of cysteine proteases. J. Biol. Chem. 270: 1525015256

Li W, Fishman MC and Yuan J (1996) Prevention of apoptosis in CNTF-dependent neurons by a mutant ICE and by viral protein CrmA but not by proto-oncogene product Bcl-2. Cell Death Differ. 3: 105-112

Lippke JA, Gu Y, Sarnecki C, Caron PR and Su MS-S (1996) Identification and characterization of CPP32/Mch2 homolog 1, a novel cysteine protease similar to CPP32. J. Biol. Chem. 271: 1825-1828

Los M, Van de Craen M, Penning LC, Shenk H, Westendorp M, Baeuerle PA, Droge W,. Krammer PH, Fiers W and Schulze-Osthoff K (1995) Requirement of an ICE/ CED-3 protease for Fas/APO-1-mediated apoptosis. Nature 375: 81-83

Maekawa T, Matsuda S, Fujisawa J, Yoshida M and Ishii S (1991) Cyclic AMP response element-binding protein, CRE-BP1, mediates the E1A-induced but not the Tax-induced trans-activation. Oncogene 6:627-632 
Martin SJ and Green DR (1995) Protease activation during apoptosis: death by a thousand cuts? Cell 82: $349-352$

Milligan CE, Prevette D, Yaginuma H, Homma S, Cardwell C, Fritz LC, Tomaselli KJ, Oppenheim RW and Schwartz LM (1995) Peptide inhibitors of the ICE protease family arrest programmed cell death of motoneurons in vivo and in vitro. Neuron 15: $385-393$

Miura M, Zhu H, Rotello R, Hartwieg EA and Yuan J (1993). Induction of apoptosis in fibroblasts by IL-1 $\beta$-converting enzyme, a mammalian homolog of the $C$. elegans cell death gene ced-3. Cell 75: 653-660

Munday NA, Vaillancourt JP, Ali A, Casano FJ, Miller DK, Molineaux SM, Yamin T-T, Yu VL and Nicholson DW (1995) Molecular cloning and pro-apoptotic activity of

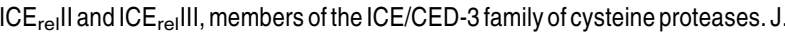
Biol. Chem. 270: 5870-15876

Muzio M, Chinnaiyan AM, Kischkel FC, O'Rourke K, Shevchenko A, Ni J, Scaffidi C Bretz JD, Zhang M, Gentz R, Mann M, Krammer PH, Peter ME and Dixit VM (1996) FLICE, a novel FADD-homologous ICE/CED-3-like protease, is required to the CD95 (Fas/APO-1) death-inducing signaling complex. Cell 85: 817-827

Nicholson DW, Ali A, Thornberry NA, Vaillancourt JP, Ding CK, Gallant M, Gareau Y Griffin PR, LabelleM, Lazebnik YA, Mungay NA, Raju SM, Smulson ME, Yamin TT, Yu YL and Miller DK (1995) Identification and inhibition of the ICE/CED-3 protease necessary for mammalian apoptosis. Nature 378: $37-43$

Niwa H, Yamamura K and Miyazaki J (1991) Efficient selection for high-expression transfectants with a novel eukaryotic vector. Gene 108: 193-200

Pickup DJ, Ink BS, Hu W, Ray CA and Koklik WK (1986) Hemorrhage in lesions caused by cowpox virus is induced by a viral protein that is related to plasma protein inhibitors of serine proteases. Proc. Natl. Acad. Sci. USA 83: 7698-7701

Quan LT, Caputo A, Bleackley RC, PickupDJ and Salvesen GS (1995) Granzyme B is inhibited by the cowpox virus serpin cytokine response modifier A. J. Biol. Chem. 270: $10377-10379$

Rabizadeh S, LaCount DL, Friesen PD and Bredesen DE (1993) Expression of the baculovirus p35 gene inhibits mammalian neuronal cell death. J. Neurochem. 61: $2318-2321$

Ray CA, Black RA, Kronheim SR, Greenstreet TA, Sleath PR, Salvesen GS and Pickup DJ (1992) Viral inhibition of inflammation, cowpox virus encodes an inhibitor of the interleukin-1 $\beta$ converting enzyme. Cell 69: 597-604

Schlegel J, Peters I, Orrenius S, Miller DK, Thornberry NA, Yamin T-T and Nicholson DW (1996) CPP32/apopain is a key interleukin $1 \beta$ converting enzyme-like protease involved in Fas-mediated apoptosis. J. Biol. Chem. 271: 1841-1844

Shimizu S, Eguchi Y, KamiikeW, Matsuda H and Tsujimoto Y (1996) Bcl-2 expression prevents activation of the ICE protease cascade. Oncogene 12: 2251-2257

Smith KGC, Strasser A and Vaux DL (1996) CrmA expression in T lymphocytes of transgenic mICE inhibits CD95(Fas/APO-1)-transduced apoptosis, but does not cause lymphadenopathy or autoimmune disease. EMBO J. 15: 5167-5176
Srinivasula SM, Ahmad M, Fernandes-Alnemri T, Litwack G and Alnemri ES (1996) Molecular ordering of the Fas-apoptotic pathway: the Fas/APO-1 protease Mch5 is a CrmA-inhibitable protease that activates multiple Ced-3/ICE-like cysteine proteases. Proc. Natl. Acad. Sci. USA. 93: 14486-14491

Sugimoto A, Friesen PD and Rothman JH (1994) Baculovirus p35 prevents developmentally programmed cell death and rescues a ced-9 mutant in the nematode Caenorhabditis elegans. EMBO J. 13: 2023-2028

Tewari M and Dixit VM (1995) Fas- and tumor necrosis factor-induced apoptosis is inhibited by the poxvirus crmA gene product. J. Biol. Chem. 270: 3255-3260

Tewari M, Quan LT, O'Rourke K, Desnoyers S, Zeng Z, Beidler DR, Poirier GG Salvesen GS and Dixit VM (1995a) Yama/CPP32 $\beta$, a mammalian homolog of CED-3, is a CrmA-inhibitable protease that cleaves the death substrate poly(ADP-ribose) polymerase. Cell 81: 801-809

Tewari M, Telford WG, Miller RA and Dixit VM (1995b) CrmA, a poxvirus-encoded serpin, inhibits cytotoxic T-lymphocyte-mediated apoptosis. J. Biol. Chem. 270: 22705-22708

Thornberry NA, Bull HG, Calaycay JR, Chapman KT, Howard AD, Kostura MJ, Mille DK, Molineaux SM, Weigner JR, Aunins J, Elliston KO, Ayala JM, Casano FJ, Chin J, Ding GJ-F, Egger LA, Gaffney EP, Limjuco G, Palyha OC, Raju SM, Rolando AM, Salley JP, Yamin T-T, Lee TD, Shively JE, MacCross M, Mumford RA, Schmidt JA and Tocci MJ (1992) A novel heterodimeric cysteine protease is required for interleukin-1 $\beta$ processing in monocytes. Nature 356: 768-774

Wang L, Miura M, Bergeron L, Zhu H and Yuan J (1994) Ich-1, an ICE/ced-3-related gene, encodes both positive and negative regulators of programmed cell death Cell 78: $739-750$

Wang X, Zelenski NG, Yang J, Sakai J, Brown MS and Golstein JL (1996) Cleavage of sterol regulatory element binding proteins (SREBPs) by CPP32 during apoptosis. EMBO J. 15: 1012-1020

Xue D and Horvitz HR (1995) Inhibition of the Caenorhabditis elegans cell-death protease CED-3 by a CED-3 cleavage site in baculovirus p35 protein. Nature 377: $248-251$

Xue D, Shaham S and Horvitz HR (1996) The Caenorhabditis elegans cell-death protein CED-3 is a cysteine protease with substrate specificities similar to those of the human CPP32 protease. Genes Dev. 10: 1073-1083

Yuan J and Horvitz HR (1990) Genetic mosaic analysis of ced-3and ced-4, two genes that control programmed cell death in nematode C. elegans. Dev. Biol. 138: 33 41

Yuan J, Shaham S, Ledoux S, Ellis HM and Horvitz HR (1993) The C. elegans cell death gene ced-3 encodes a protein similar to mammalian interleukin- $1 \beta$ converting enzyme. Cell 75: 641-652 